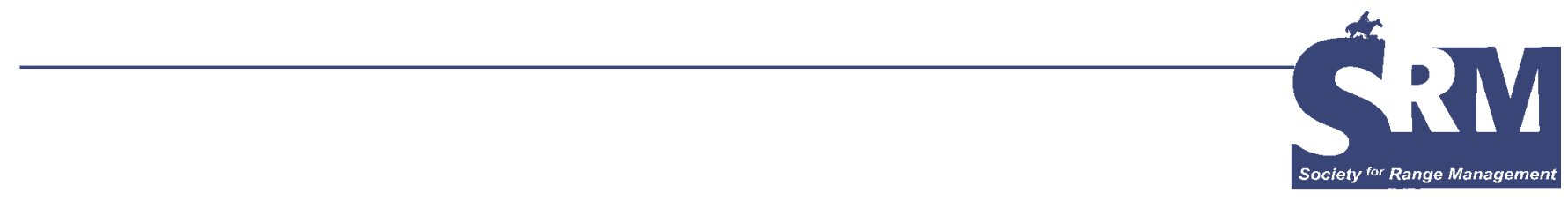

\title{
Distribution of Public and Private Benefits on Federally Managed Community Pastures in Canada
}

\section{By Suren Kulshreshtha, George Pearson, Brant Kirychuk, and Rick Gaube}

$\mathrm{P}$ ublic lands traditionally managed for agricultural purposes are seeing increased usage and value for other uses. The Prairie Farm Rehabilitation Administration (PFRA) managed Community Pasture Program (CPP) in Canada is no exception. Although the program was developed for both conservation and livestock production purposes, there is a realization of CPP lands' value and contribution to other sectors of society. The $\mathrm{CPP}$ is a unique grazing land management program in that it provides full care for livestock during the grazing season, and recovers the costs associated with providing grazing and breeding services from those clients. Recognizing that there are multiple users and benefits to Canadian society, a study was undertaken to examine the costs and benefits associated with these uses, and the relationship to setting grazing and breeding service fees.

\section{History of the Community Pasture Program}

Prairie agriculture was severely challenged in the 1930s by rangeland degradation resulting from drought, economic depression, and inappropriate policies for marginal land use. These events left the lands in the region severely eroded, resulting in a loss of means to provide decent economic returns to the farmers and a good quality of life to their families. Many of the farmers decided to leave the Prairies, particularly in southeastern Alberta and southwestern

KIRYCHUK, B., N. BedARD, AND B. Houston. 2006. A national approach to sustainable grassland management. Unpublished manuscript. Regina, Saskatchewan, Canada: Prairie Farm Rehabilitation Administration. $18 \mathrm{p}$.
Saskatchewan. Other regions of the Prairies were also affected, although not to the same magnitude.

Abandoned degraded agricultural lands became a noticeable problem in the Prairie provinces, as was the need for their restoration. The Government of Canada, through the creation of a new agency, PFRA, provided a portion of the solution in 1935. By 1936, the agency had developed several programs, among them the CPP.

A total of 87 community pastures were developed under the auspices of the CPP on the abandoned lands in the provinces of Alberta, Saskatchewan, and Manitoba with the assistance of provincial governments (in the form of assembling the land). The major objective of the program was to rehabilitate and conserve lands that had been subjected to severe drought and wind erosion. An equally important purpose in establishing the pastures was to help advance economic stability and diversification in the Prairie provinces. Most of the land within these pastures was extremely marginal for annual crop production (predominantly Canada Land Inventory Classes 5 and 6). A typical landscape in a community pasture is shown in Photo 1.

\section{Description of the PFRA Community Pasture Program}

It was apparent that the best use of these lands for conservation and economic purposes was to graze livestock. Although the pastures started in the most degraded areas of the brown soil zone, over time the program has built up to include at-risk land in other areas of the Prairies, to reach a current total land area of 2.3 million acres (about 929,357 ha). Of this total area, $73.1 \%$ of the land is classed as native grassland, $16 \%$ is seeded pasture, $8 \%$ is woodland, and 


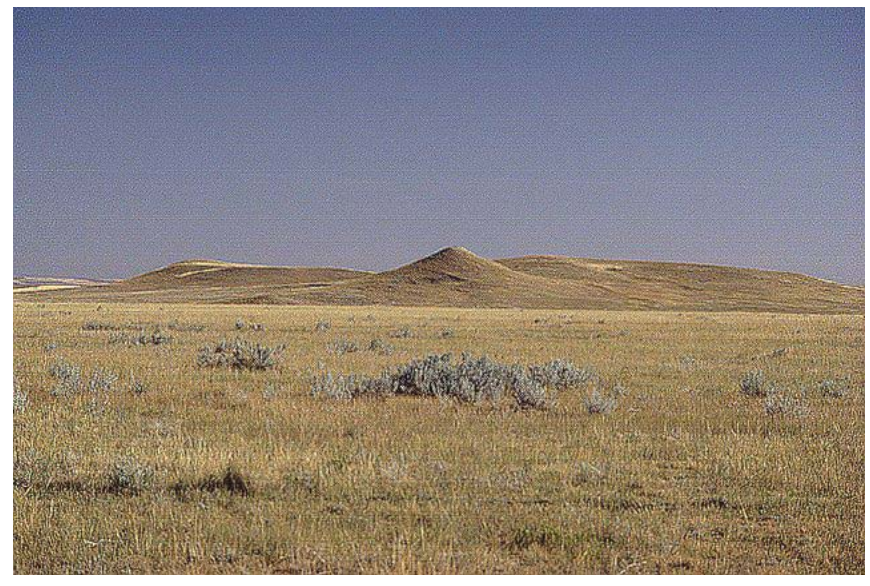

Photo 1. A general landscape of community pastures.

Total Land Area in PFRA Community Pastures -- 2.3 Million Acres (929,357 Hectares)

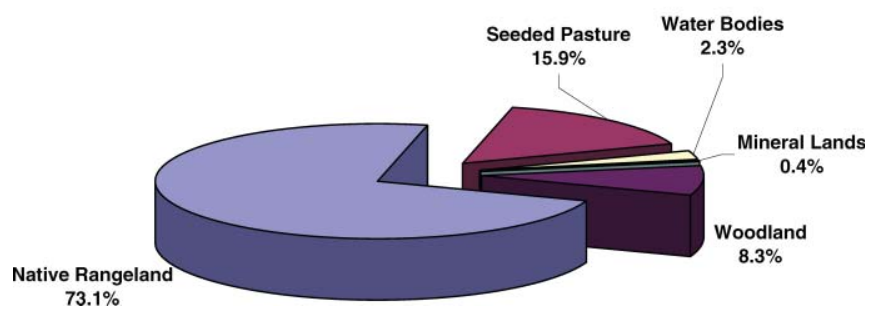

Figure 1. Land use on Prairie Farm Rehabilitation Administration (PFRA) community pastures.

slightly more than $2 \%$ is occupied by water bodies (Fig. 1). Plant communities vary somewhat among land management districts, with community pastures located in the black soil zone of Saskatchewan and Manitoba having higher frequency of woodland and water bodies. In contrast, open grassland dominates the pastures of southern Saskatchewan and Alberta (Photo 2).

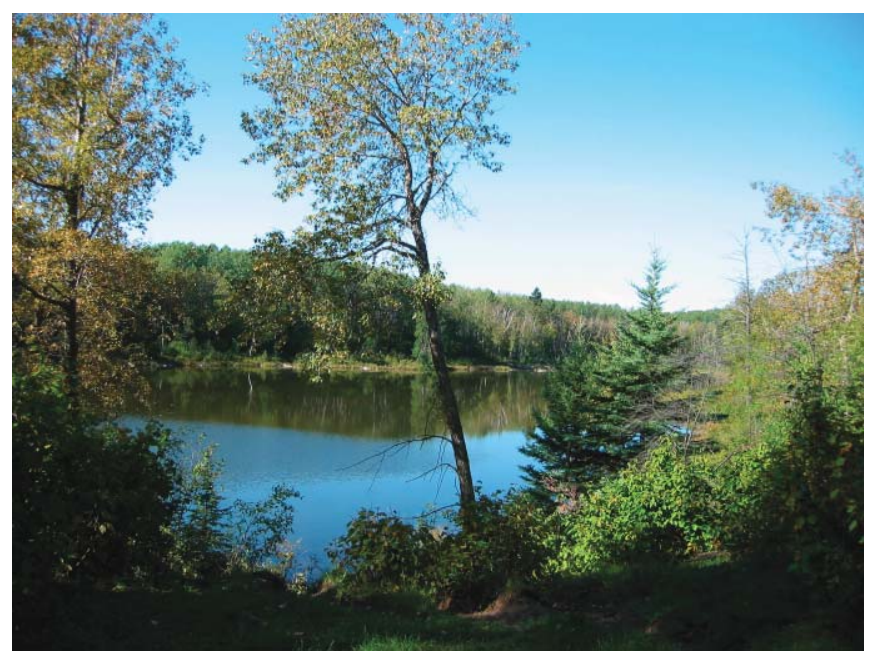

Photo 2. Presence of water bodies in some community pastures.

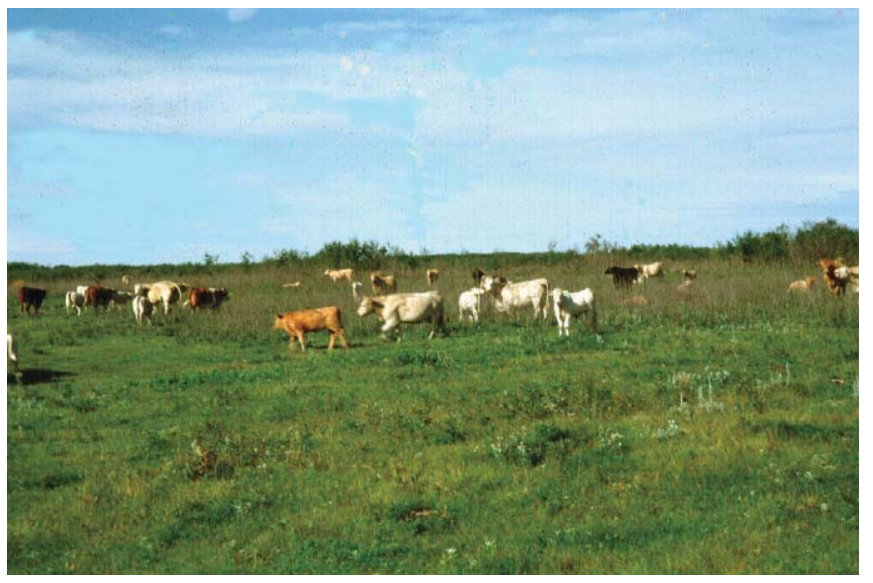

Photo 3. Grazing activities at a community pasture.

Of the total 87 PFRA-managed community pastures in 2006, 24 were in Manitoba, 62 were in Saskatchewan, and one was situated on a Canadian Forces base in Alberta. These pastures vary in size from 5,000 to 111,000 acres $(2,023$ to $44,920 \mathrm{ha})$ in size, with the average pasture encompassing an area of approximately 25,000 acres $(10,117 \mathrm{ha})$. Close to 4,000 livestock producers (called patrons hereafter) use the pastures each summer, grazing about 225,000 headii of livestock (Photo 3). The livestock consist mainly of beef cows and calves, although other cattle, such as yearlings and bulls, also are present. Several pastures also carry horses and foals, besides cattle and calves. The program is designed to help producers strengthen their operations by providing grazing and breeding service.

Each community pasture is managed by a resident manager, although in some cases a manager oversees two small adjacent pastures. These managers look after thousands of acres of rangeland and hundreds of head of livestock, treat sick animals, bale hay, and repair equipment and fences. The PFRA has built more than 1,000 dugouts, 770 wells, 420 windmills, and 130 dams on community pastures to provide water to livestock and wildlife.

The pasture year begins in November when pasture patrons apply to bring their livestock to the pastures. Patrons must apply annually, although priority is given to those who used the pasture previously. The applications trigger a planning process involving the development of grazing plans, determining carrying capacity of the rangeland in each pasture, and acquiring bulls that will be needed. Livestock arrivals begin in May and can stretch to the end of June. The length varies from year to year, depending upon weather conditions and the needs of patrons. Horses typically begin arriving on the first of June. Over the summer,

In the 2004-2005 year, 52.8\% of all livestock on community pastures were cows (dry and breeders). Another $44.8 \%$ of the total livestock was calves (including pasture-born calves). The remaining $2.4 \%$ of these livestock were bulls and horses (including a small number of colts) on community pastures. The composition of these livestock is subject to change from year to year because there are no long-term arrangements made for any patron. 

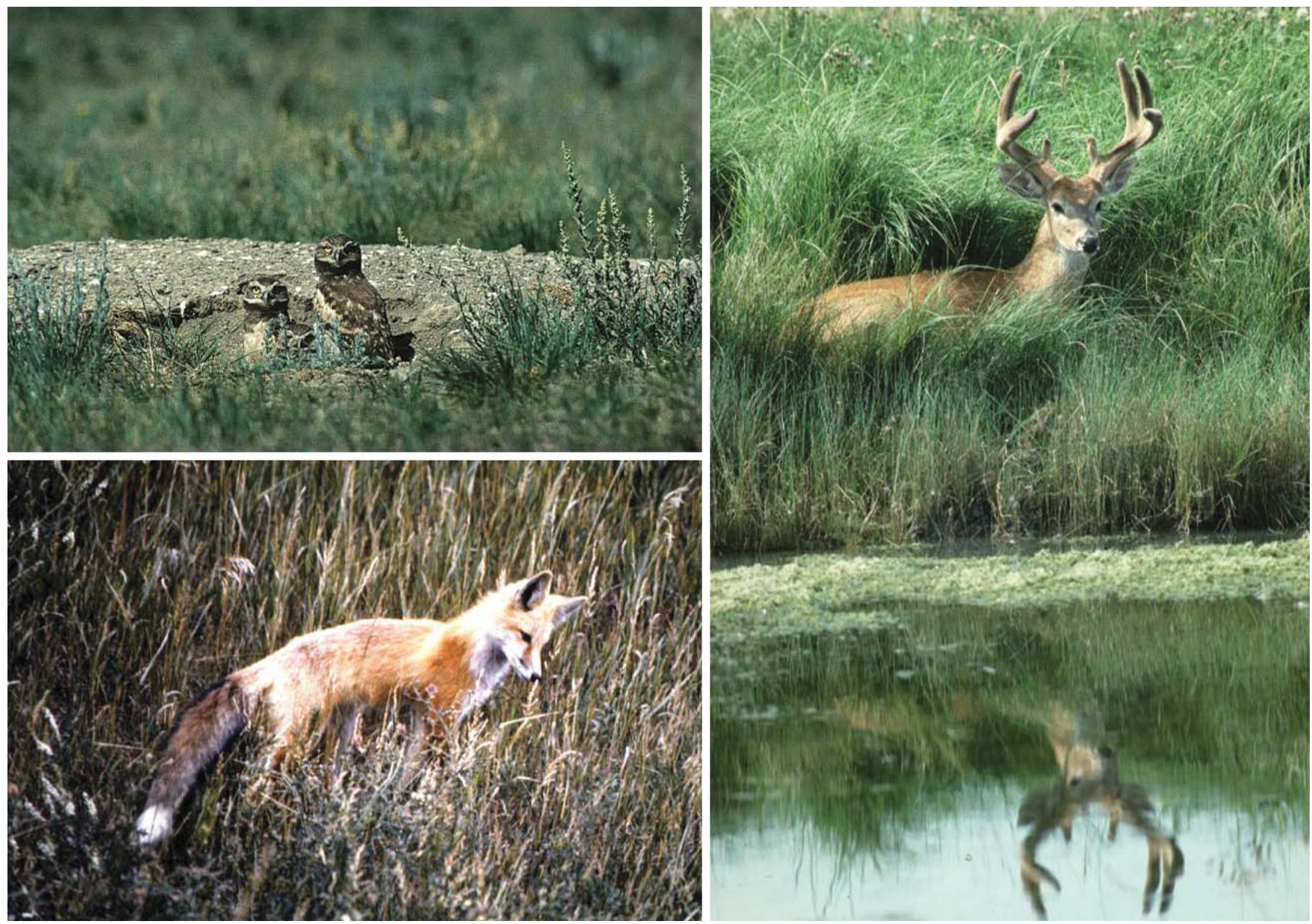

Photo 4. Wildlife habitats provided by community pastures.

livestock are checked at least once per week and rotated over different paddocks.

Cows and mares are bred on various community pastures. To help improve the quality of western cattle, about 3,000 high-quality bulls are provided for this purpose. Some of these bulls are rented ${ }^{\mathrm{iii}}$ from the patrons of the community pasture, whereas the rest are maintained by PFRA. After 1 August, rented bulls are picked up by the owners and PFRA-owned bulls are put in fields away from cows.

The pastures also provide areas for a variety of nonagricultural activities such as logging, hunting, outdoor recreation, preservation of archeological sites, and research. Some of these sites provide year-round critical habitat for wildlife, including endangered species, such as the ferruginous hawk, burrowing owl, and swift fox. In Saskatchewan, 49 of the 62 pastures provide homes for "species-at-risk" (Photo 4).iv

\footnotetext{
iii During 2004-2005, a total of 862 bulls were rented from patrons.

iv Species-at-risk include threatened and endangered plant and animal species. Species-at-risk protection is a priority issue both within Canada and internationally. As of May 2002, it was determined that there are 402 species-at-risk in Canada, of which 11 are extinct. Most invertebrates, micro-organisms, and lower plants have not yet been evaluated to determine their status.
}

\section{Issue of Cost Recovery for Public Programs}

Operations of the CPP are financed though two sources of funds: fees paid by patrons for the use of various pasture services, and payments made by the Government of Canada's Agriculture and Agri-Food Canada. Costs are recovered pursuant to cost recovery principles approved by the Government of Canadav in April 1979. The cost recovery principles recognized two primary objectives of the CPP:

- Objective I: Conservation of the Resource (costs borne by Canada)

- Objective II: Provision of Services (costs borne by patrons)

Usually, Objective II program costs are fully recovered through fees for grazing, breeding, and miscellaneous services charged to community pasture patrons. Thus, through proper land use changes, the original mandate of the community pastures program (i.e., reducing soil drifting and stabilizing soil conditions in various parts of the Prairies) continues to be met to this day.

\footnotetext{
These guidelines are based on TREASURY BOARD OF CANADA. User charging in the federal government-a background document. Available at: http://www.tbs-sct.gc.ca/pubs_pol/opepubs/TB_H/UCFG_e.asp. Accessed 20 March 2006.
} 
By employing land management practices initiated over many years, the PFRA community pastures have become a major source of summer forage for cattle grazing and, in turn, have assisted in fostering greater economic security, stability, sustainability, and diversification within the Prairies. At the same time, a number of other uses and benefits, in addition to cattle grazing and breeding, have evolved from community pastures.

Over time, PFRA has tried to maintain a system of charges for community pasture uses that bears a fair relationship with the benefits received by patrons, the contribution of rangelands to the public good, and comparable charges for grazing privileges on provincial and private pastures. Under conditions of joint provision for several types of benefits, determination of user fees/charges requires a careful consideration of costs and benefits associated with providing various services.

The Treasury Board has mandated various federal government departments to examine options for validating or changing cost recovery charges for many services, especially where public expenditures bestow private benefits on individuals or companies. In its December 1997 report to the House of Commons, the Office of the Auditor General of Canada noted that PFRA "needs to determine what is a private benefit rather than a public benefit, and what portion of the private benefit should be recovered". ${ }^{\text {vi }}$ To do this, PFRA needed a sound basis of measurement for defining costs and benefits. A cost-recovery formula should ideally reflect a distribution of charges among the various pasture resource users that fairly reflects both the distribution and magnitude of the costs incurred on behalf of, and benefits received by, various pasture resource users. The objective of this study was to define a framework for cost recovery. Subsequently, this framework was applied to determine the share of annual cost of operating community pastures for various CPP beneficiaries.

\section{Methodology}

The approach followed in this study was to validate and apply a methodology based on sound economic principles for estimation of benefits and equitable distribution of costs among various users of community pastures operated by Agriculture and Agri-Food Canada (AAFC)-PFRA. The central premise of this methodology is "beneficiary pay principle." More details on this methodology are presented by Kulshreshtha and Pearson, vii which was updated in

vi Office of the Auditor General of Canada. 1997. Report of the Auditor General of Canada to the House of Commons. Chapter 24. Ottawa, Ontario, Canada: Agriculture and Agri-Food Canada-Prairie Farm Rehabilitation Administration. 488 p.

vii This methodology is presented in two reports: KULSHRESHTHA, S. AND G. G. PEARSON. 2000. Economic framework for cost recovery on federal community pastures, a report submitted to the Prairie Farm Rehabilitation Administration, Regina, Centre for Studies in Agriculture, Law, and Environment. Saskatoon, Saskatchewan, Canada: University two recent studies. ${ }^{\text {vii }}$ Our work required developing methodologies for estimating costs and benefits from the CPP (including who benefits), and for dividing the costs among various beneficiaries in a fair and equitable manner. The first issue was addressed through development of "total economic value" of the resource and its various constituents, and "total economic costs." The second issue was handled through an apportionment methodology called Separable CostsRemaining Benefits (SCRB). One of the main pillars of this estimation is that all costs that are incurred for a single purpose (called separable costs in this methodology) should be borne by that user only. The remaining costs (i.e., those incurred for more than one user, called common costs) are shared using an equitable apportionment method.

The overall methodology of estimation was divided into four major steps: 1) collection of data on the total direct, indirect, and implicit costs of community pasture operation and investment within a total economic cost accounting framework; 2) determination of direct and indirect benefits to various users from PFRA community pasture resources; 3) classification of costs into various user/beneficiary groups and adjustment of costs as appropriate; and 4) application of the SCRB methodology for apportioning costs and calculating a cost recovery level. A schematic of various steps involved in determination of a cost recovery level for private and public beneficiaries of community pastures is presented in Figure 2.

\section{Estimation of Cost of Operations}

Estimation of the cost of operating the federal community pastures was complicated by the fact that although some expenses are directly associated with the CPP activities, there are services that are provided either jointly with other non-CPP activities or some services used by the CPP that are not explicitly expensed. The latter types of cost items were valued at their respective opportunity costs. In order to arrive at the total economic cost of the CPP, expenditures at three levels were summed. These included 1) community pasture manager level, 2) land manager district level, and 3) PFRA Headquarter level. Some of the cost items were related to infrastructure, and therefore have a multiyear life. These were converted into annual costs using a 5\% rate of interest and remaining life of the asset in question.

One of the major issues in estimating total economic cost was the inclusion of value of land. An arguments for its

of Saskatchewan. CSALE Working Paper \#3. xii + 105 p. and in Kulshreshtha, S. N., AND G. G. PeArSON. 2002. Estimation of cost recovery levels on federal community pastures under joint private and public benefits. Saskatoon, Saskatchewan, Canada: Department of Agricultural Economics, University of Saskatchewan. 171 p.

viii Kulshreshtha, S. N., And G. G. Pearson. 2006. An update on determination of a cost recovery framework and fee schedule formula for the Agriculture and Agri-Food Canada-Prairie Farm Rehabilitation Administration community pasture program. Saskatoon, Saskatchewan, Canada: University of Saskatchewan. 122 p. 


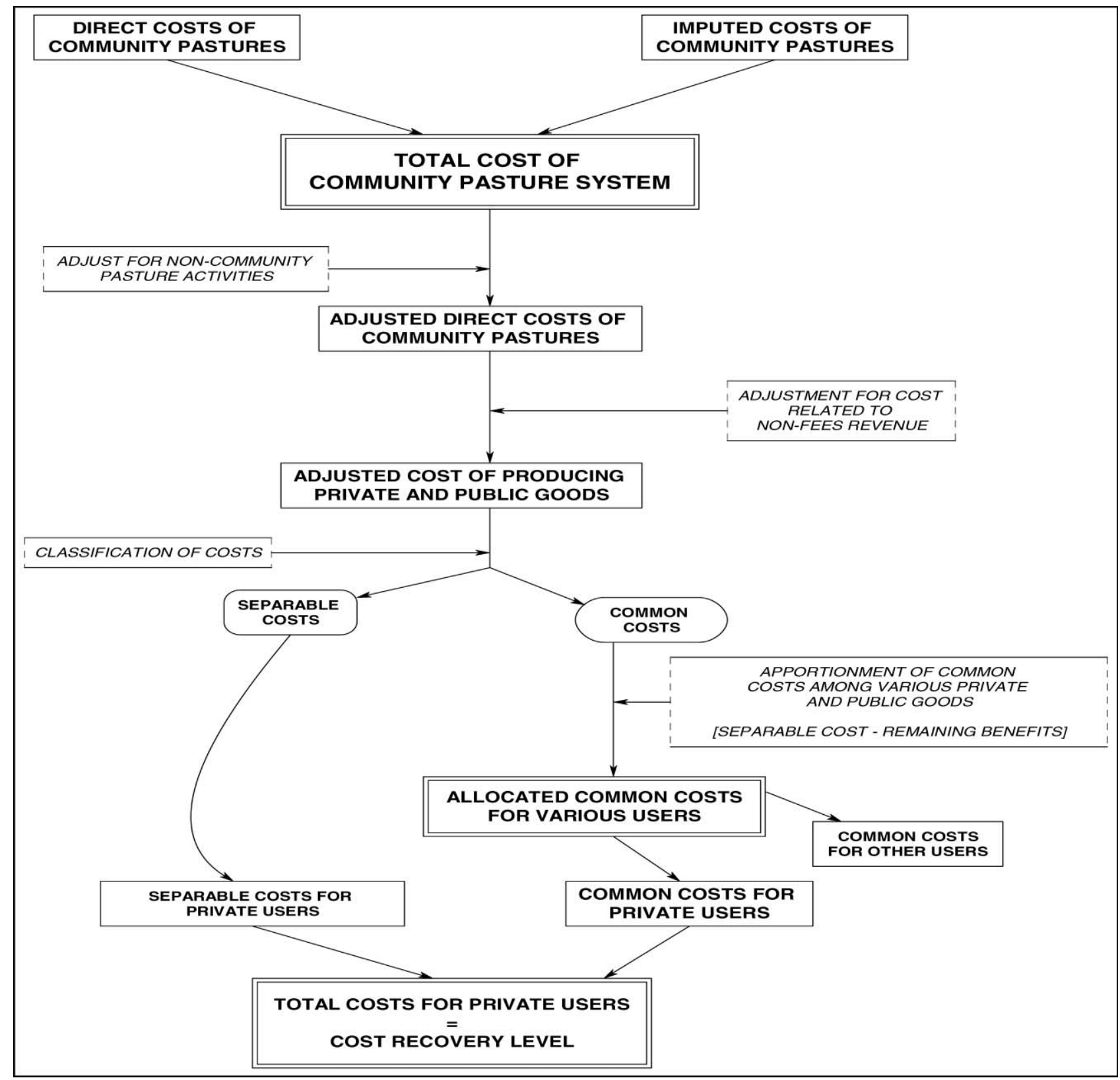

Figure 2. Determination of the cost recovery level for private and public beneficiaries of community pastures.

inclusion is that land that is occupied has an opportunity cost to society and thus should be paid for by various beneficiaries. An argument against inclusion of this cost in setting user fees is that all costs must be actually paid. Because the federal government acquired much of the land base under CPP at no cost, and some lands are loaned by the provincial government, inclusion of this cost can be challenged legally. In the final analysis, land costs were excluded from our study.

\section{Estimation of Benefits}

The first step in estimating benefits was to identify various user groups and the benefits they derive from the CPP.
To this end, we undertook a survey of community pasture managers. Each manager was asked to identify various potential benefits to society (user group) and the magnitude of the benefit. This resulted in a total of 24 types of benefits, categorized into five types of goods and services received by three benefiting groups (Table 1). These were 1) private users of the services (private goods or benefits); 2) society at large, called public goods or benefits, which were further divided into three subgroups-ecosystem function-related benefits, provision of social goods, and impact on external parties; and 3) the federal (and to a certain extent provincial and local) government (fiscal benefits). Total value of benefits for all the three groups was estimated at (Canadian) 


\begin{tabular}{|c|c|c|c|c|}
\hline \multirow[b]{2}{*}{$\begin{array}{l}\text { Private } \\
\text { benefits }\end{array}$} & \multirow[b]{2}{*}{$\begin{array}{l}\text { Public goods (ecosystem } \\
\text { function-related) } \\
\text { benefits }\end{array}$} & \multicolumn{2}{|c|}{$\begin{array}{l}\text { Quasi-public/private goods } \\
\text { related benefits }\end{array}$} & \multirow[b]{2}{*}{ Fiscal benefits } \\
\hline & & $\begin{array}{c}\text { Social } \\
\text { goods-related } \\
\text { benefits }\end{array}$ & $\begin{array}{l}\text { Other external } \\
\text { benefits }\end{array}$ & \\
\hline Grazing & Carbon sequestration & $\begin{array}{l}\text { Wildlife/waterfowl } \\
\text { hunting }\end{array}$ & Soil conservation & $\begin{array}{l}\text { Reduced program payments } \\
\text { resulting from land use changes }\end{array}$ \\
\hline Breeding & Biodiversity & $\begin{array}{l}\text { Wildlife/waterfowl } \\
\text { non-hunting } \\
\text { activities }\end{array}$ & $\begin{array}{l}\text { Community/rural } \\
\text { development }\end{array}$ & $\begin{array}{l}\text { Commercial activities } \\
\text { (non-fees) related revenues }\end{array}$ \\
\hline $\begin{array}{l}\text { Access } \\
\text { to water }\end{array}$ & Wildlife/waterfowl habitats & $\begin{array}{l}\text { Other recreational } \\
\text { activities }\end{array}$ & $\begin{array}{l}\text { Access for scientific } \\
\text { research* }\end{array}$ & Benefits to rural municipalities* \\
\hline \multirow[t]{4}{*}{$\begin{array}{l}\text { Damage } \\
\text { to crops }\end{array}$} & $\begin{array}{l}\text { Endangered species } \\
\text { preservation }\end{array}$ & Heritage sites & Technology transfer* & - \\
\hline & Fragile ecosystem protection & - & Income distribution* & - \\
\hline & $\begin{array}{l}\text { Watershed/wetlands } \\
\text { protection }\end{array}$ & - & $\begin{array}{l}\text { Other commercial } \\
\text { activities }\end{array}$ & - \\
\hline & Flood protection* & - & - & - \\
\hline
\end{tabular}

$\$ 58.3$ million. Because fiscal revenues to the federal government were not related to the community pasture activities, these were deducted, leaving a total benefit of $\$ 54.9$ million per annum, as shown in Table 2. Similarly, benefits to the local governments were also excluded from this analysis.

\section{Classification of Total Cost}

In order to appropriately apportion costs to various user groups, total costs need to be classified into two types: separable costs and common costs. The former refers to expenditures in providing a benefit to a designated user group that are directly related to that user group. These are single benefit items, and can include capital costs and operating costs. If the expenditure resulted in benefits accruing to two or more groups, then the cost was classified as a common cost. We found that $22 \%$ of the total costs were separable costs, i.e., incurred for one and only one benefit group.

\section{Apportionment of Total Cost to Various Benefit Groups}

The cost recovery level for various users of community pastures was estimated using the SCRB method. In applying this method, a new criterion, single purpose cost of the system, was estimated. The cost to be allocated to a benefit group was based on the lesser of the benefits to the group or the cost of that project if built for a single purpose. From this value, separable costs were netted out, leaving only justifiable common costs. These common cost items were apportioned using the distributional weights for the justifiable common costs. Separable and common costs for a given benefit group were summed to yield total allocated cost of the CPP for the given benefit group.

Before applying this procedure, a simplifying assumption was made that any fiscal benefits accruing to the federal government would be counted as a reduction in the cost of operating the CPP, and do not have to be recovered through user fees. Similarly, fiscal benefits to provincial or local governments were excluded. These included savings in program payments for land in the community pastures and nongrazing activities, such as gravel and mineral extraction, oil and gas exploration, and logging.

\section{Results of Analysis}

The analysis encompassed the estimation of costs, the valuation of benefits, and the calculation of a basic cost recovery scenario for PFRA community pastures. The estimated total cost of all the AAFC-PFRA community pastures under the base scenario (no land costs included) was estimated at $\$ 22.0$ million per annum. Distribution of this total cost by primary private and public user categories is shown in Figure 3.

Costs related to private users of PFRA pastures were associated primarily with grazing and breeding activities. Estimated total costs for these activities were $\$ 11.6$ million. All other costs are associated with uses that benefit the public directly or indirectly as members of the society. Costs associated with the primary benefits of soil conservation, 
Table 2. Estimated value of annual benefits and allocation of adjusted costs-by-benefits category-Prairie Farm Rehabilitation Administration community pastures, 2004 Canadian dollars

\begin{tabular}{|c|c|c|c|c|c|c|}
\hline \multirow[b]{2}{*}{ Category of benefits } & \multicolumn{3}{|c|}{$\begin{array}{l}\text { Estimated value of benefits in } \\
\text { thousands of dollars }\end{array}$} & \multicolumn{3}{|c|}{$\begin{array}{l}\text { Allocation of adjusted costs } \\
\text { in thousands of dollars }\end{array}$} \\
\hline & Private & Public & Total & $\begin{array}{l}\text { Private } \\
\text { uses }\end{array}$ & $\begin{array}{l}\text { Public } \\
\text { uses }\end{array}$ & $\begin{array}{l}\text { Total } \\
\text { uses }\end{array}$ \\
\hline Grazing & 16,801 & - & 16,801 & 8,532 & - & 8,532 \\
\hline Breeding (less bull sales) & 4,160 & - & 4,160 & 3,059 & - & 3,059 \\
\hline $\begin{array}{l}\text { Uncompensated crop damage and water } \\
\text { access }\end{array}$ & 6 & - & 6 & 6 & - & 6 \\
\hline Soil conservation & - & 2,095 & 2,095 & - & 793 & 793 \\
\hline $\begin{array}{l}\text { Land use conversion (program payment } \\
\text { savings) }\end{array}$ & - & 0 & 0 & - & 0 & 0 \\
\hline Wildlife and waterfowl recreation (hunting) & - & 3,805 & 3,805 & - & 1,119 & 1,119 \\
\hline Other recreation & - & 2,571 & 2,571 & - & 760 & 760 \\
\hline Community development & - & 4,649 & 4,649 & - & 1,365 & 1,365 \\
\hline Carbon sequestration & - & 20,545 & 20,545 & - & 6,033 & 6,033 \\
\hline Biodiversity & - & 204 & 204 & - & 60 & 60 \\
\hline $\begin{array}{l}\text { Scientific research, heritage sites, } \\
\text { endangered species and watershed } \\
\text { protection }\end{array}$ & - & 92 & 92 & - & 230 & 230 \\
\hline Fragile ecosystems protection & - & 0 & 0 & - & 1 & 1 \\
\hline Non-pasture revenue from commercial uses & - & 14 & 14 & - & 4 & 4 \\
\hline $\begin{array}{l}\text { Program total benefits and adjusted } \\
\text { costs }\end{array}$ & 20,967 & 33,976 & 54,943 & 11,598 & 10,368 & 21,967 \\
\hline $\begin{array}{l}\text { Program ratio of benefits to costs } \\
\text { (annual) }\end{array}$ & & & & & & \\
\hline Distribution of benefits and costs (\%) & 38.2 & 61.8 & 100 & 52.8 & 47.2 & 100 \\
\hline
\end{tabular}

Distribution of Total PFRA Community Pasture Costs by Major Beneficiary Categories -- \$22 Million

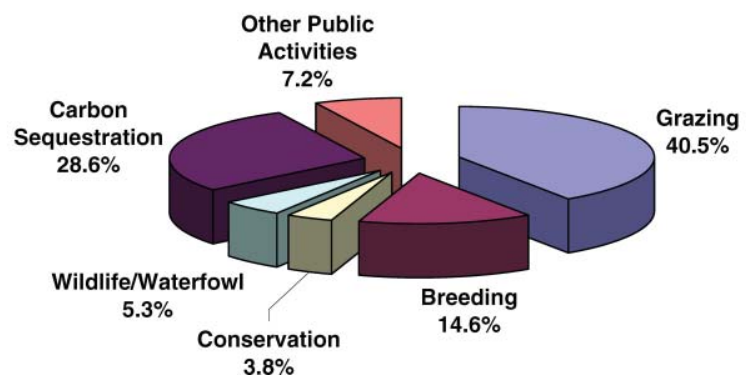

Figure 3. Estimated Prairie Farm Rehabilitation Administration (PFRA) community pasture annual costs, 2004 Canadian dollars. wildlife and waterfowl hunting, and for carbon sequestration were estimated at $\$ 0.8, \$ 1.1$, and $\$ 6.0$ million, respectively. The costs of other public and social uses totaled $\$ 2.5$ million.

Distribution of total benefits and costs by individual categories of benefits are shown in Table 2 for all federallymanaged community pastures. Corresponding to $\$ 22.0$ million in total costs for all the PFRA-managed community pastures, total benefits to society (including patrons of the community pastures) at $\$ 54.9$ million yields a ratio ${ }^{\mathrm{ix}}$ of

* The calculation of this ratio should not be confused with that from a benefit-cost analysis, where past and/or future benefits and costs are estimated and values are discounted using an appropriate discount rate. 
benefits to costs of 2.5. A ratio of this magnitude indicates that the total annual value of private and public benefits derived from PFRA community pastures is far greater than the total annual operating cost of the CPP. However, these results are only for one year and therefore subject to yearto-year variability. Furthermore, no consideration was made in this estimation for the future benefits or for discounting them.

For the total community pasture system, private users' costs were estimated to be $53 \%$ of the total, whereas costs for public goods (excluding non-fee revenue activities) represented $47 \%$ of the total. At the same time, private benefits represented $38 \%$ of total benefits and public benefits were estimated to be $62 \%$ of total benefits. This disproportionally higher share of total cost to be borne by private users is a result of several cost items that were solely for these private users, and thus should be borne by them.

The estimated value of benefits derived from the primary community pasture private and public user categories for the base scenario is illustrated by Table 2 and Figure 4. Benefits related to private users of PFRA pastures, associated primarily with grazing and breeding activities, were estimated to total $\$ 21.0$ million.

All other benefits were considered to be received by the public directly or indirectly as federal taxpayers and members of society. Public benefits associated with the primary categories of soil conservation, wildlife and waterfowl hunting, and carbon sequestration were estimated at $\$ 2.1$, $\$ 3.8$, and $\$ 20.5$ million, respectively. Other public benefits, including nonpasture revenue from commercial uses, were estimated to total $\$ 7.6$ million.

The private share of benefits from the CPP was estimated to be $38.2 \%$ of the total. However, on account of high level of separable costs, private benefits are responsible

There were no leasehold values either for grazing or leasing. All patrons are required to apply for their allotment on an annual basis.

\section{Distribution of Total Benefits from CPP $=\$ 54.9$ Million}

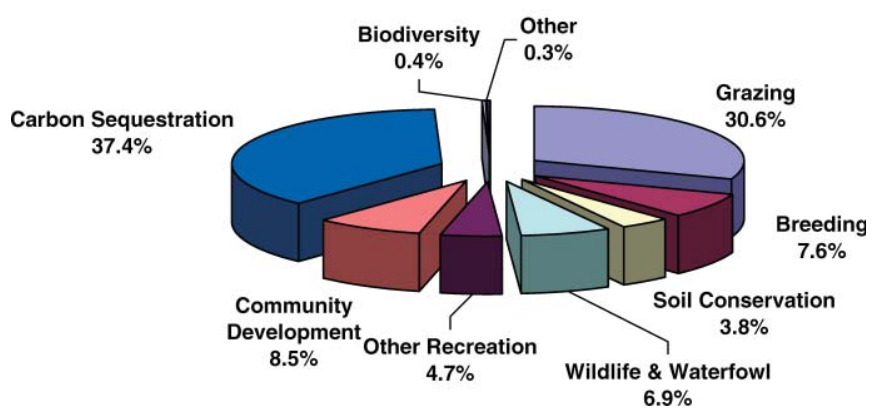

Figure 4. Distribution of total benefits per annum from the Community Pasture Program (CPP), 2004. for $53 \%$ of the total cost. Thus, the user fees, if imposed on private patrons, should be such that they return revenues to the federal government of $\$ 11.6$ million. The rest of the cost should be borne by the society at large, which is generally paid for by the federal government.

One major limitation of the results presented in this section is that the data used in this study pertain to a single year of operations. These costs and benefits are likely to change over time. In addition, there can also be considerable site-to-site variability in these values. However, in defense of these results, it should be noted that the data resulting in benefits of community pastures were based on an average level confirmed by various community pasture managers.

\section{Implications of Results}

Multifunctionality applies to the federal Community Pastures Program in the Canadian Prairie provinces. In addition to being a source of direct revenues to the federal government and providing an invaluable service to patrons, it generates benefits to various members of society. On account of this, it will be grossly unfair to patrons to fully absorb the total cost of the CPP. It is reasonable to argue that all beneficiaries must pay a fair share of the costs of operating the community pastures. For the patrons, this study has shown that the fair share is approximately one-half of the total cost (over and above the direct revenues to the federal government from various nonagricultural activities). The remaining costs should be borne by other members of the society. Because imposition of user charges for this vast array of public users is impractical, on account of higher transactions costs of such measures, the most practical method by which operations of the CPP are financed is for the federal government to contribute one-half of the total costs on behalf of Canadian society. This system would ensure that society continues to receive such benefits.

\section{Conclusion}

It is evident that public rangelands have a variety of benefits to livestock producers, other direct users, and society as a whole. The costs of operating these pastures are not solely associated with providing grazing and breeding services, and thus must be apportioned fairly to all users. It is possible to estimate the benefits and costs associated with publicly managed rangeland. It is recognized that there are different management models for rangeland in various jurisdictions. Thus, costs are different and benefits will certainly vary among ecosystems and jurisdictions. Although the values presented in this paper are somewhat representative of all Canadian Prairie rangelands, the costs and benefits for public land managed in other jurisdictions would undoubtedly have different values. This methodology of accounting for benefits and costs would be applicable to other areas and land ownership patterns. 


\section{Acknowledgments}

We would like to thank AAFC-PFRA for the financial support provided for this study.

Authors are Professor of Agricultural Economics, University of Saskatchewan, Saskatoon, SK S7N 5A8, Canada, suren. kulshreshtha@usask.ca (Kulshreshtha); President, Pearson and Associates Agri-Consulting Inc., Saskatoon, SK S7K 6X7, Canada (Pearson); Assistant Director, Ag-Lands and Agroforestry, Agriculture and Agri-Food Canada, Regina, SK S4P 4L2, Canada (Kirtchuk); and Manager, Land Management, Agriculture and Agri-Food Canada, Regina, SK S4P 4L2, Canada (Gaube). 